\title{
Entry of Rabies Virus in the Olfactory Bulb of Mice and Effect of Infection on Cell Markers of Neurons and Astrocytes
}

\author{
Ingreso del Virus de la Rabia en el Bulbo Olfatorio de Ratones y \\ Efecto de la Infección en Marcadores Celulares de Neuronas y Astrocitos \\ Orlando Torres-Fernández ${ }^{1}$; Natalia Andrea Daza ${ }^{1}$; Gerardo Santamaría-Romero; \\ Andrea P. Hurtado ${ }^{1}$ \& Jeison Monroy-Gómez ${ }^{1,2}$
}

TORRES-FERNÁNDEZ, O.; DAZA, N. A.; SANTAMARÍA-ROMERO, G.; HURTADO,A. P. \& MONROY-GÓMEZ, J. Entry of rabies virus in the olfactory bulb of mice and effect of infection on cell markers of neurons and astrocytes. Int. J. Morphol., 36(2):670$676,2018$.

SUMMARY: There are few studies of infection by rabies virus in the olfactory bulb (OB). This work was carried out with the purpose of establishing the time required to detect rabies antigens in the $\mathrm{OB}$ of mouse, after the intramuscular inoculation of the virus and to evaluate the effect of the infection on the expression of three proteins: calbindin (CB), parvalbumin (PV) and the glial fibrillary acidic protein (GFAP). Mice were inoculated with rabies virus intramuscularly in the hind limbs. Every 8 hours, after 72 hours postinoculation (p.i.), animals were sacrificed by perfusion with paraformaldehyde and coronal sections of OB were obtained for immunohistochemical study. These cuts were used to reveal the entry and spread of viral antigens. Tissue sections obtained in the terminal phase of the disease (144 hours p.i.), and controls of the same age were also processed for immunohistochemistry of CB, PV and GFAP. Rabies virus antigens were initially detected at 80 hours p.i. in a few mitral cells. At 88 hours p.i. the antigens had spread through most of these neurons but until the terminal phase of the disease there was little dispersion of the virus towards other cellular layers of the OB. The CB protein was expressed in cells of the glomerular stratum, the PV in cells of the outer plexiform layer and the GFAP was expressed in all the layers of the OB. Viral infection generated loss of CB expression and increase of PV expression. Immunoreactivity to GFAP was increased in the outer plexiform layer of the $\mathrm{OB}$ as a response to infection.

KEY WORDS: Rabies; Olfactory bulb; Calbindin; Parvalbumin; GFAP, Immunohistochemistry.

\section{INTRODUCTION}

Rabies is a disease with a fatal outcome caused by a neurotropic virus. The virus enters with the saliva of an infected animal to the nerve endings of the host. Then by retrograde axonal transport it enters the central nervous system. Although rabies can be prevented by vaccination, it applies only to people at increased risk of infection, and it is almost impossible to eradicate a virus that has wild vectors. For this reason it is necessary to do basic research on the pathogenic mechanisms of the virus within the nervous system to find therapeutic alternatives (Hemachudha et al., 2013). In mammals, the olfactory bulb (OB) is a primordial organ for survival; intervenes in reproduction, provision of food, scent marking, and in many other aspects of social behavior. The OB is equivalent to the brain lobe that is responsible for receiving and processing information from the chemoreceptors of the olfactory epithelium (Nagayama et al., 2014) and its alteration has been associated with neurological disorders such as Parkinson's disease and Alzheimer's disease (Kovács, 2004). In addition, the OB is an entry route to the central nervous system of many pathogenic viruses, including rabies virus (van Riel et al., 2015). The works directed to study the infection by rabies virus in the $\mathrm{OB}$ are scarce. This investigation was carried out with the purpose of establishing the time required to detect rabies antigens in the $\mathrm{OB}$ and its subsequent dissemination, after the intramuscular inoculation of the virus and to evaluate the effect of the infection on the expression of two proteins used as neuronal markers: calbindin (CB) and parvalbumin (PV) and the glial fibrillary acidic protein (GFAP), a marker of astrocytes. These markers have been used to evaluate different neurological diseases in nervous tissue (Permyakov \& Kretsinger, 2011; Sullivan, 2014).

\footnotetext{
${ }^{1}$ Grupo de Morfología Celular, Dirección de Investigación en Salud Púbica, Instituto Nacional de Salud, Bogotá, Colombia.

${ }^{2}$ Departamento de Ciencias Básicas, Institución Universitaria Escuela Colombiana de Rehabilitación, Bogotá, Colombia.
} 


\section{MATERIAL AND METHOD}

Inoculation and handling of laboratory animals. Female ICR mice (Institute of Cancer Research) of 4 weeks of age were used. These animals were kept in the vivarium of the National Institute of Health of Colombia (INS), under nutritional and environmental conditions in accordance with legal and ethical standards. The management protocol was endorsed by the INS Ethics Committee. A total of 40 animals were used, 23 inoculated with the virus and 17 controls. The inoculations were performed on the hamstring muscles of the hind limbs with a solution containing rabies virus type CVS (Challenge Virus Standard). Each animal was injected with $0.03 \mathrm{ml}$ of $1 \times 10^{-6}$ dilution equivalent to $10^{4.49}$ LD50. The controls were inoculated with the diluent solution (vehicle) devoid of the virus (Torres-Fernández et al., 2004). The immunohistochemical study of CB, PV and GFAP markers was carried out with animals that reached the terminal phase of the disease (144 hours p.i.). This was characterized by poor movement, paralysis of the hind limbs, reduced body size, low weight and body surface cold to the touch. Five sick animals and their respective controls were anesthetized by means of an injection of $0.2 \mathrm{ml}$ of $30 \%$ chloral hydrate intraperitoneally $(350 \mathrm{mg} / \mathrm{kg})$. In three minutes the mice were under deep anesthesia. A similar procedure was followed with the animals destined to establish the time of entry and dispersion of the viral antigens within the OB. For this purpose, 3 animals were sacrificed at 72, 80, 88, 96, 120 and 144 post-inoculation hours (p.i.). Simultaneously, two controls were sacrificed for each of the schedules.

Fixation by perfusion, extraction and cutting of the olfactory bulb. Once anesthetized, the animals were fixed by intracardiac perfusion. Through the apex of the left ventricle an insulin syringe needle was inserted which was connected to a peristaltic pump used to drive the liquids used in the perfusion. Then a phosphate buffered saline solution (PBS) was run at $\mathrm{pH} 7.3$ for 5 minutes and then a $4 \%$ paraformaldehyde fixative solution (PFA) (70 $\mathrm{ml}$ of solution for 10 minutes). After completing the perfusion with the fixative, PBS was again allowed to circulate for two minutes. The skull was then cut to remove the brain in one piece, avoiding damaging the $\mathrm{OB}$, and transferred to fresh fixative solution for 24 hours at $\pm 4{ }^{\circ} \mathrm{C}$. The hemispheres were separated with a blade to cut the $\mathrm{OB}$ of each hemisphere separately and include it in agar. The blocks of agar with the tissue were placed in a vibratome. Coronal sections of the OB $50 \mu \mathrm{m}$ thick in the rostro-caudal direction were obtained to initiate the immunohistochemical treatment.

Immunohistochemistry. The OB was processed for immunohistochemistry in less than two weeks after perfusion. The sections were collected and transferred to small Petri dishes with a diameter of $1.5 \mathrm{~cm}$. Each contained PBS solution with $0.02 \%$ sodium azide. Between 12 and 15 cuts were placed in each box and left on a horizontal rotatorshaker at room temperature $20^{\circ} \mathrm{C} \pm 2$ until the next day. In these same conditions of temperature and permanent agitation the whole immunohistochemical procedure was carried out. To initiate, the cuts were washed with PBS at $\mathrm{pH} 7.3$; these washes were repeated after each treatment during the process. After the first wash, the cuts were treated with $0.02 \mathrm{M}$ ammonium chloride $\left(\mathrm{NH}_{4} \mathrm{Cl}_{2}\right)$, for 20 minutes, to minimize the residual effect of the aldehydes and with 3 $\%$ hydrogen peroxide $\left(\mathrm{H}_{2} \mathrm{O}_{2}\right)$, for 20 minutes, to inactivate the endogenous peroxidase. The sections were then incubated for 30 minutes in normal serum and bovine serum albumin to block nonspecific sites.

The blocking solution was then removed and, without washing, the sections were left overnight in incubation with the primary antibody prepared in PBS. Primary anti-CB and anti-PV monoclonal antibodies (Sigma, in 1: 2500 dilutions), and a polyclonal anti-GFAP antibody (Dako, in 1: 1000 dilution) were used. After washing, incubation with the secondary antibody (anti-mouse biotinylated $\mathrm{IgG}$ or antirabbit IgG biotinylated Sigma in dilution 1: 600) was carried out for two hours. Then the cuts were treated with the ABC Vector $^{\circledR}$ solution (avidin-biotin-peroxidase complex) for a period of two hours. Finally, immunostaining was performed using the chromogen diaminobenzidine (DAB). The cuts were mounted on glass slides pretreated with $1 \%$ gelatin. They were allowed to dry at room temperature and mounted with Entellan (Merck). A similar protocol was followed to carry out the immunohistochemical study of the antigens of the rabies virus with the purpose of confirming the presence and spread of the virus in the OB. To this end, an antirabies antiserum (dilution 1: 2500) prepared in rabbits was used (Lamprea et al., 2010).

Histological and digital analysis of the images. Initially qualitative observations were made of the immunohistochemical preparations, both of the infected samples and their controls, to confirm the presence and distribution of the antigens, as well as the morphological characteristics of the positive cells for each of the markers and the viral antigen. In order to perform the quantitative analysis of the markers, we proceeded to take counts of immunoreactive cells to $\mathrm{CB}(\mathrm{CB}+), \mathrm{PV}(\mathrm{PV}+)$ and GFAP $(+)$ in the OB sections of the infected animals and the controls, using a microscope with Zeiss Netzmier mesh of 1 $\mathrm{mm}^{2}$. The analysis was carried out with samples taken from five infected animals and their controls (experimental units) for each of the markers. Cell counts were performed by exploring six fields per cut with the $10 \mathrm{X}$ objective within 
the area defined for the panoramic counts in each OB cut. Each field in $10 \mathrm{X}$ is equivalent to an area of $0.25 \mathrm{~mm}^{2}$. The statistical method used was the Wilcoxon distribution, which corresponds to ideal non-parametric statistics for small samples (3 to 8 samples) (Torres-Fernández et al.).

\section{RESULTS}

Infection with the rabies virus in the olfactory bulb of mice. The first $\mathrm{OB}$ neurons infected with the rabies virus were observed at 80 hours post-inoculation (p.i.) and corresponded, due to their location and size, to mitral cells (Fig. 1). At 88 hours p.i. the infection had spread through

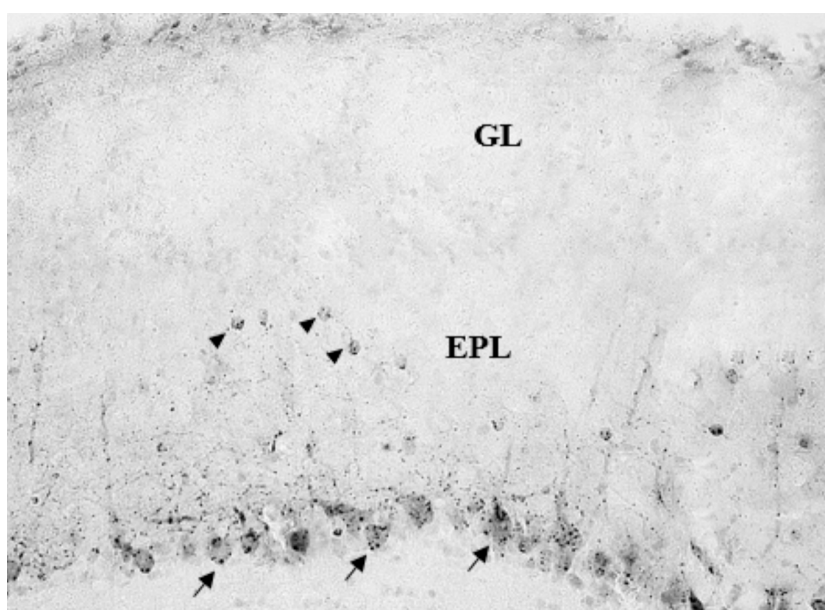

Fig. 1. Mitral cells infected with rabies virus in mouse olfactory bulb. The immunoreactivity of viral antigens demarcates the contour of the cell body (arrows) and fragments of some dendrites. In the outer plexiform layer (EPL) some tuft cells are also noticed immunoreactive (arrowheads). GL: glomerular layer. DAB-Nickel (10X).

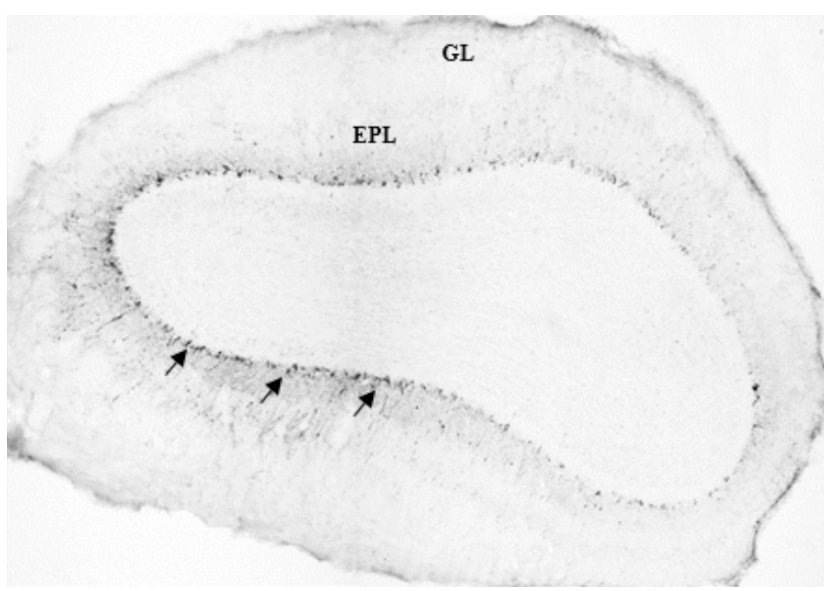

Fig. 2. Immunoreactivity of the infection with the rabies virus observed in the mitral cell belt (arrows) in a coronal section of the mouse olfactory bulb. GL: glomerular layer; EPL: external plexiform layer. DAB-Nickel $(2.5 \mathrm{X})$
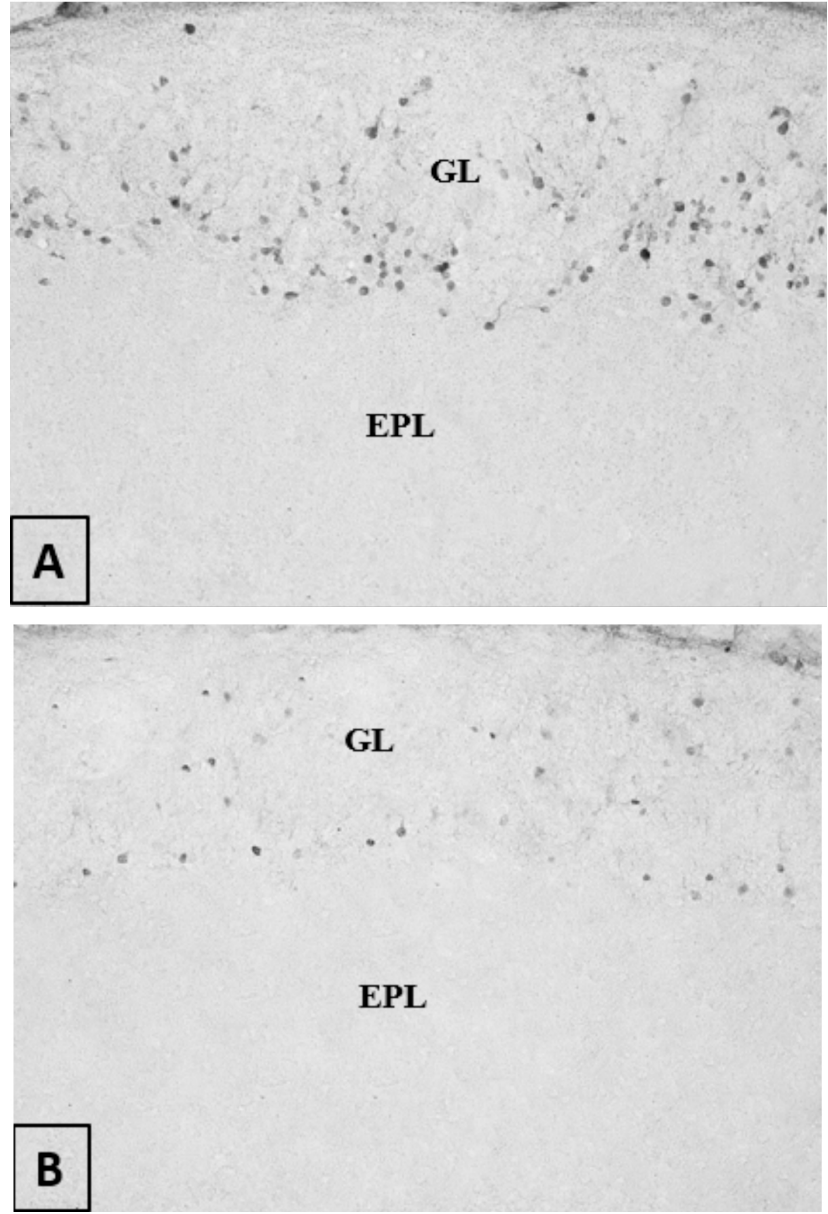

Fig. 3. A. Distribution of $\mathrm{CB}+$ cells in a cross-sectional fragment of the olfactory bulb of a control mouse. The neurons immunoreactive to $\mathrm{CB}$ are located in the glomerular layer (GL). EPL: external plexiform layer. DAB-Nickel (10X). B. Fragment of a cross section of mouse olfactory bulb inoculated with rabies virus. The loss of $\mathrm{CB}+$ cells and their lower immunostaining in the glomerular layer (GL) is evident. EPL: external plexiform layer. DAB-Nickel (10X).

almost the entire mitral cell layer (Fig. 2). However, until the terminal phase of the disease ( $144 \mathrm{~h}$ p.i.), the distribution of viral antigens remained almost unchanged, except for some tufted cells located within the outer plexiform stratum that also had immunoreactivity to the rabies virus antigens.

Immunoreactivity of CB in the olfactory bulb of control and infected mice. In a panoramic view in cross sections of the $\mathrm{OB}$, cells immunoreactive to $\mathrm{CB}$ were observed only in the glomerular layer (Fig. 3a). The immunostaining allowed a detailed description of morphology of the soma or cell bodies: Neurons with rounded or slightly oval soma cells and an average diameter of $7.5 \mathrm{~mm}(\mathrm{n}=20)$ predominated in the controls. The average number of $\mathrm{CB}+$ neurons counted in the entire ring of the glomerular layer was 340 in the 

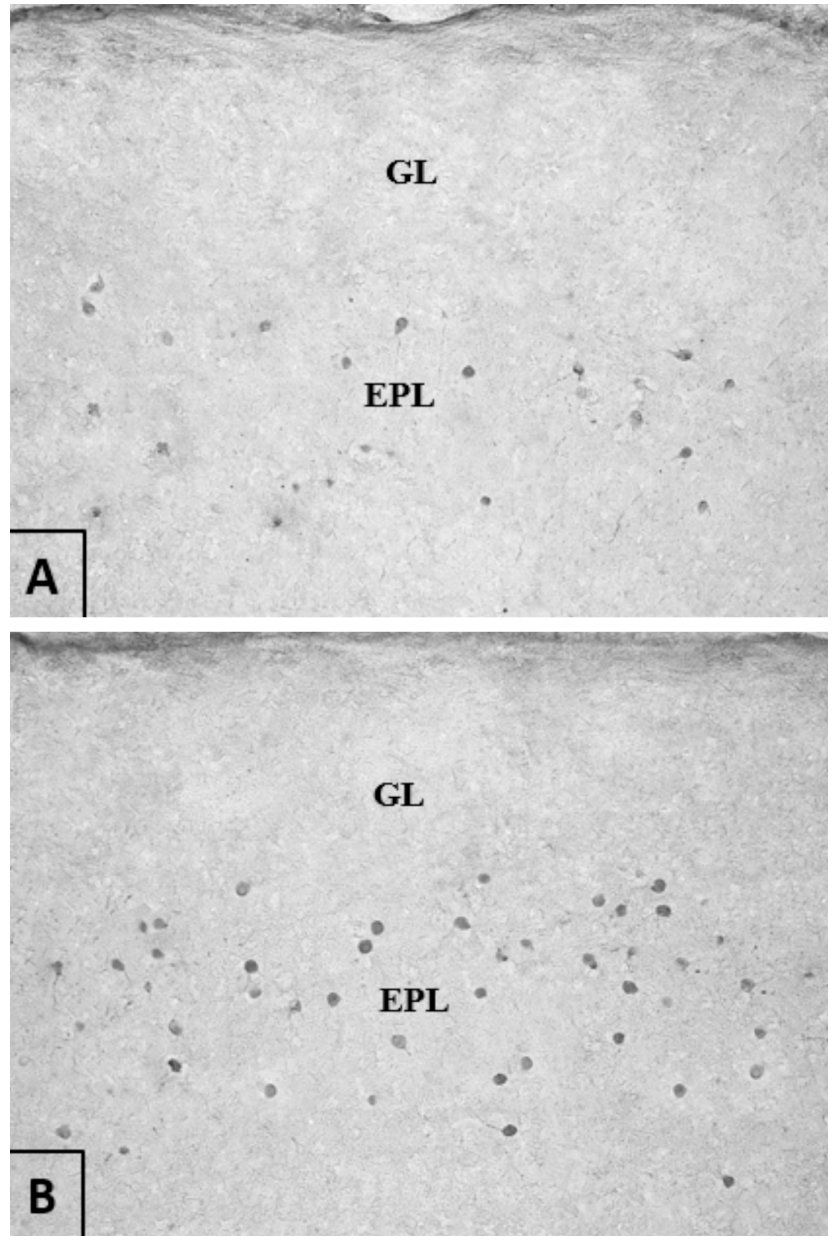

Fig. 4. A. Distribution of PV+ cells in a cross-sectional fragment of the olfactory bulb of a control mouse. The neurons immunoreactive to PV are located only in the outer plexiform layer (EPL); GL: glomerular layer (10X). B. Fragment of a cross section of mouse olfactory bulb inoculated with rabies virus. The increase of PV immunoreactive cells in the external plexiform layer (EPL) is evident. GL: glomerular layer. (10X)

controls (Table I). The infection with the rabies virus generated a statistically significant decrease in the number of CB + cells of the inoculated animals (controls 340, infected $196, p=0.0079$ ) (Fig. 3b) (Table I). The diameter of the cells was also lower $6.5 \mathrm{~mm}(\mathrm{n}=20)$ in the infected ones.

Immunoreactivity of PV in the olfactory bulb of control and infected mice. In a panoramic observation of transverse sections of the $\mathrm{OB}$, the presence of immunoreactive cells to $\mathrm{PV}$ was demonstrated only in the external plexiform layer (Fig. 4a). Immunostaining revealed in detail the morphology of the neuronal soma: neurons with rounded or oval cell bodies and an average diameter of $9.5 \mathrm{~mm}(\mathrm{n}=20)$ predominated in the controls. The average of $\mathrm{PV}+$ neurons counted in the entire concentric band of the external
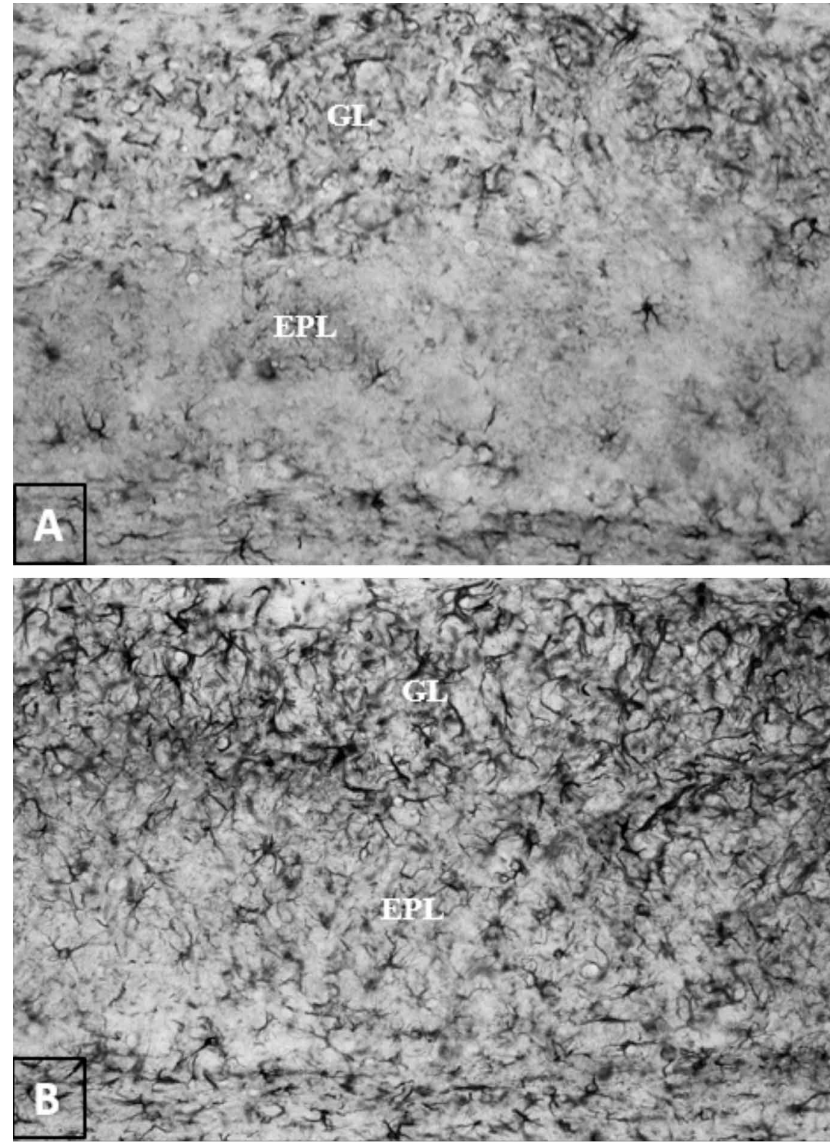

Fig. 5.A. Fragment of a cross-section of olfactory bulb in a control mouse that shows greater immunoreactivity to GFAP in the glomerular layer (GL) compared to the external plexiform layer (EPL). DAB-Nickel (10X). B. Fragment of a cross section of olfactory bulb in a mouse inoculated with rabies virus. Note the increase of GFAP immunoreactive cells in the outer plexiform layer (EPL). GL: glomerular layer. DAB-Nickel (10X).

plexiform layer of the OB was 110 in the controls (Table II). The infection with the rabies virus generated an increase in the number of $\mathrm{PV}+$ cells in the inoculated animals (controls 110; infected 165; $\mathrm{p}=0.0317$ ) (Fig. 4b) (Table II). The average diameter of the $\mathrm{PV}+$ neurons in the infected ones was also higher: $10.2 \mathrm{~mm}(\mathrm{n}=20)$.

\section{Immunoreactivity of GFAP in the olfactory bulb of con-} trol and infected mice. In the coronal sections of $O B$ observed in a panoramic view, the abundance of somas and cellular processes of the astrocytes revealed by immunostaining for GFAP in all layers was remarkable. When the histological preparations were analyzed qualitatively, at higher magnification, the difference in the immunoreactivity of the external plexiform layer between the controls and the animals inoculated with the rabies virus was evident. The viral infection generated a remarkable 
Table I. Data on the number of immunoreactive cells to $\mathrm{CB}$ in the glomerular layer (GL) in coronal sections of the olfactory bulb of mice inoculated with rabies virus and its controls. For each sample, three sections were examined; each value corresponds to the total number of positive cells in a single cut. Counts were made in $40 \mathrm{X}$ objective.

\begin{tabular}{|c|c|c|c|c|c|}
\hline \multirow[b]{2}{*}{ Sample } & \multicolumn{2}{|c|}{ Controls } & \multicolumn{2}{|c|}{ Infected } & \multirow[b]{2}{*}{$\mathrm{p}$-Value } \\
\hline & Mean & SD & Mean & $\mathrm{SD}$ & \\
\hline 1 & 339.0 & 70.2 & 209.0 & 46.7 & \multirow{6}{*}{$0.0079 * *$} \\
\hline 2 & 321.0 & 71.0 & 159.7 & 5.5 & \\
\hline 3 & 337.0 & 90.8 & 187.3 & 51.1 & \\
\hline 4 & 406.0 & 60.1 & 234.0 & 18.5 & \\
\hline 5 & 297.0 & 94.3 & 190.3 & 25.1 & \\
\hline Mean & 340.0 & 40.5 & 196.0 & 27.5 & \\
\hline
\end{tabular}

$\mathrm{SD}$, Standard Deviation ** statistically significant.

Table II. Data on the number of immunoreactive cells to PV in the external plexiform layer (EPL) in coronal sections of the olfactory bulb of mice inoculated with rabies virus and its controls. For each sample, three sections were examined; each value corresponds to the total number of positive cells in a single cut. Counts were made in $40 \mathrm{X}$ objective.

\begin{tabular}{crrrrr}
\hline \multirow{2}{*}{ Sample } & \multicolumn{2}{c}{ Controls } & \multicolumn{2}{c}{ Infected } & \multirow{2}{*}{-V Mean } \\
& \multicolumn{1}{c}{ SD } & Mean & SD & \\
\hline 1 & 142.0 & 5.2 & 188.3 & 36.1 & \\
2 & 128.3 & 24.9 & 211.3 & 11.1 & \\
3 & 108.7 & 14.0 & 134.0 & 25.2 & $0.0317 * *$ \\
4 & 86.7 & 9.0 & 162.3 & 15.5 & \\
5 & 83.0 & 20.8 & 131.7 & 25.4 & \\
Mean & 109.7 & 25.6 & 165.5 & 34.5 & \\
\hline
\end{tabular}

$\mathrm{SD}$, Standard Deviation ** statistically significant.

Table III. Data on the number of cells immunoreactive to GFAP in the external plexiform layer (EPL) in coronal sections of the olfactory bulb of mice inoculated with rabies virus and its controls. For each sample, three sections were examined; each value corresponds to the total number of positive cells in a single cut. Counts were made in $40 \mathrm{X}$ objective.

\begin{tabular}{cccccc}
\hline \multirow{2}{*}{ Sample } & \multicolumn{2}{c}{ Controls } & \multicolumn{2}{c}{ Infected } & \multirow{2}{*}{-Valor } \\
& Mean & \multicolumn{1}{c}{ SD } & Mean & SD & \\
\hline 1 & 127.0 & 10.8 & 257.7 & 25.1 & \\
2 & 118.7 & 19.0 & 249.3 & 54.0 & \\
4 & 128.7 & 27.4 & 323.0 & 28.8 & \\
4 & 191.3 & 8.1 & 320.0 & 20.3 & $0.0079^{* *}$ \\
5 & 188.3 & 20.6 & 373.7 & 76.8 & \\
Mean & 150.8 & 35.8 & 304.7 & 51.5 & \\
\hline
\end{tabular}

$\mathrm{SD}$, Standard Deviation ** statistically significant. increase in the number of GFAP+ cells to such an extent that it was difficult to establish the boundary between the glomerular and external plexiform layers (Figs. 5a and 5b). The count of immunoreactive astrocytes to GFAP counted around the perimeter of the external plexiform layer showed a significant difference (controls 150, infected 304, p = 0.0079) (Table III).

\section{DISCUSSION}

Infection with the rabies virus in the mouse olfactory bulb. The infection with the rabies virus was detected in the OB after 80 hours p.i. The first neurons infected were mitral cells. This is explained because they are the projection neurons that communicate the OB with the cerebral cortex. The rabies virus inoculated by the intramuscular route enters the cerebral cortex after 64 hours p.i. (Torres et al., 2015). Since this virus is disseminated by retrograde axonal transport (Hemachudha, et al.) it must first reach the cerebral cortex and from there be taken up by the axons of the mitral cells. The little spread of the virus from the mitral cells to the interneurons (cells of the glomerular and plexiform strata) is striking, even in the advanced phase of the disease (5-6 days post-inoculation) despite its proximity and multiple interconnections. This could explain why in OB the dendrodendritic connections predominate because most of their interneurons do not have an axon (Crespo et al., 2013; Kato el al., 2013; Nagayama et al.), therefore, the lack of axodendritic or axosomatic connections between the interneurons and the projection neurons (mitral cells and tufted cells), would make it difficult to transport the virus between the latter and the neighboring interneurons.

Normal distribution of $\mathrm{CB}$ and $\mathrm{PV}$ in the mouse olfactory bulb. There are few studies published about the distribution of $\mathrm{CB}$ and $\mathrm{PV}$ in the mouse $\mathrm{OB}$, most of them have been done in rats. In this study, CB-immunoreactive neurons were observed mainly in the glomerular layer of OB whereas PV+ cells were detected only in the external plexiform layer. This distribution coincides with that reported for CB and PV in mice by Qin et al. (2005) who also found no expression of these proteins in mitral cells. The work of these authors was carried out with the same strain of mice (ICR) but they were male animals; even so, the distribution of proteins was similar to that found in females. Currently there are researchers who emphasize confirming neurohistological and neurochemical findings in both sexes because sexual dimorphism has been found in different areas of the nervous system including OB (de Vries \& Forger, 2015). Other authors have confirmed the immunoreactivity of $\mathrm{CB}$ in the glomerular stratum (Kosaka \& Kosaka, 2004) and PV in the 
external plexiform layer (Kato et al.) of the mouse OB. The distribution of immunoreactive neurons to $\mathrm{CB}$ and $\mathrm{PV}$ in the mouse OB is similar to that found in studies in rats and other mammals: shrews, moles, hedgehogs and bats (Kosaka $\&$ Kosaka), however, the distribution of these proteins are different in primate OB (Alonso et al., 2001), including humans (Ohm et al., 1991). In fact, it is considered that studies on calcium binding proteins in the rodent $\mathrm{OB}$ are not extrapolated to primates (Alonso et al.).

Effect of rabies on the expression of $\mathrm{CB}$ and PV. In this work it was observed that the infection with the rabies virus induces loss of $\mathrm{CB}+$ cells and increase in the number of $\mathrm{PV}+$ neurons of the mouse $\mathrm{OB}$. The fact that they decrease or increase the neural counts of immunoreactive cells to $\mathrm{CB}$ or PV does not imply that there is loss or increase in the number of neurons. A protein can decrease its concentration inside the cells, as was the case with $\mathrm{CB}$, without this implying neuronal death (Unal-Cevik et al., 2004). Neither can the increase in PV+ cell counts be interpreted as an increase in the number of neurons (Torres-Fernández et al., 2004). Probably some cells that had low concentration of the protein increased it until they became easily visible with the immunohistochemical reaction. Previous studies in molecular biology of rabies confirm that although the infection tends to induce loss in the expression of the vast majority of proteins, a smaller percentage of them increases their expression, apparently those that the virus requires to facilitate their dispersion within the nervous tissue (Prosniak et al.,2001; Farahtaj et al., 2013). Recently we have reported an increase in the expression of MAP2 induced by rabies (Hurtado et al., 2015). In previous studies conducted by our group the rabies virus produced decreased CB immunoreactivity and increased PV in the cerebral cortex, striatum and spinal cord of mice (Torres-Fernández et al., 2004; Torres-Fernández et al., 2005; Monroy-Gómez \& Torres-Fernández, 2013). All the previous results seem to indicate that the tendency to decrease the expression of $\mathrm{CB}$ and the increase of PV in the nervous system of mice inoculated with the rabies virus is constant. This may have implications for neuronal function because these proteins contribute to maintaining the intracellular calcium concentration stable (Permyakov \& Kretsinger; Zündorf \& Reiser, 2011).

Effect of rabies infection on GFAP expression. Little is known about the expression of GFAP in the OB. In rats GFAP immunoreactivity was found distributed across all layers (Chiu \& Greer, 1996) similar to what was observed in mice in the present study. On the other hand, GFAP is a marker of astrocytes and published studies about the effect of rabies on astroglia are scarce; research has focused mainly on neurons, because viral particles have only been found sporadically within the glial cells. Rabies virus is essentially neuronotropic. In addition, histopathological descriptions of infected nerve tissue report only an incipient glial reaction (Iwasaki \& Tobita, 2002; Hemachudha et al.). However, we have found glial reaction in the OB of mice infected with rabies in the terminal phase of the disease. This could be quantified in the external plexiform layer that revealed a notable difference between the controls, with few cells immunoreactive to GFAP and those infected with a large number of cells positive for GFAP.

In conclusion, in this work we have found an effect of the infection with the rabies virus on the expression of $\mathrm{CB}$ and $\mathrm{PV}$, two neuronal proteins that regulate the concentration of calcium and on GFAP, the main marker of astrocytes. These changes could reflect the effect of infection with the rabies virus on calcium metabolism. It has been found that viral infections can affect calcium signals (Permyakov \& Kretsinger) and that in experimentally induced traumatic conditions the calcium intake increases astrocytes and this induces the overexpression of GFAP (Gao et al., 2013).

\section{ACKNOWLEDGMENTS}

This work was funded by Departamento Administrativo de Ciencia, Tecnología e Innovación COLCIENCIAS and Instituto Nacional de Salud (INS, Colombia). Code of Grant 210465740573, Contract 639/2014. The author APH was financed by Colciencias and INS under the state program 'Young Researchers and Innovators', Contract 617/2015.

\section{TORRES-FERNÁNDEZ, O.; DAZA, N. A.; SANTAMARÍA- ROMERO, G.; HURTADO, A. P. \& MONROY-GÓMEZ, J.} Ingreso del virus de la rabia en el bulbo olfatorio de ratones y efecto de la infección en marcadores celulares de neuronas y astrocitos. Int. J. Morphol., 36(2):670-676, 2018.

RESUMEN: Son escasos los estudios de la infección por virus de la rabia en el bulbo olfatorio (OB). Este trabajo se realizó con el objetivo de establecer el tiempo requerido para detectar antígenos de rabia en el $\mathrm{OB}$ del ratón, luego de la inoculación intramuscular del virus y evaluar el efecto de la infección en la expresión de tres proteínas: calbindina (CB), parvoalbúmina (PV) y la proteína ácida fibrilar glial (GFAP). Los ratones fueron inoculados con virus de la rabia por vía intramuscular en las extremidades posteriores. Cada 8 horas, después de 72 horas de inoculación (p.i.), los animales se sacrificaron por perfusión con paraformaldehído y se obtuvieron secciones coronales de OB para el estudio inmunohistoquímico. Estos cortes se usaron para revelar la entrada y propagación de antígenos virales. Las secciones de 
tejido obtenidas en la fase terminal de la enfermedad (144 horas p.i.), y los controles de la misma edad también se procesaron para inmunohistoquímica de CB, PV y GFAP. Los antígenos del virus de la rabia se detectaron inicialmente a las 80 horas p.i. en unas pocas células mitrales. A las 88 horas p.i. los antígenos se habían diseminado a través de la mayoría de estas neuronas, pero hasta la fase terminal de la enfermedad había poca dispersión del virus hacia otras capas celulares del OB. La proteína CB se expresó en las células del estrato glomerular, la PV en células de la capa plexiforme externa y la GFAP se expresó en todas las capas del OB. La infección viral generó pérdida de expresión de $\mathrm{CB}$ y aumento en la expresión de PV. La inmunorreactividad a GFAP aumentó en la capa plexiforme externa del OB como respuesta a la infección.

PALABRAS CLAVE: Rabia; Bulbo olfatorio; calbindina; Parvoalbúmina; GFAP; inmunohistoquímica.

\section{REFERENCES}

Alonso, J. R.; Briñon, J. G.; Crespo, C.; Bravo, I. G.; Arévalo, R. \& Aijón, J. Chemical organization of the macaque monkey olfactory bulb: II. Calretinin, calbindin D-28k, parvalbumin, and neurocalcin immunoreactivity. J. Comp. Neurol., 432(3):389-407, 2001.

Chiu, K. \& Greer, C. A. Immunocytochemical analyses of astrocyte development in the olfactory bulb. Brain Res. Dev. Brain Res., 95(1):28-37, 1996.

Crespo, C.; Liberia, T.; Blasco-Ibáñez, J. M.; Nácher, J. \& Varea, E. The circuits of the olfactory bulb. The exception as a rule. Anat. Rec. (Hoboken), 296(9):1401-12, 2013.

de Vries, G. J. \& Forger, N. G. Sex differences in the brain: a whole body perspective. Biol. Sex Differ., 6:15, 2015.

Farahtaj, F.; Zandi, F.; Khalaj, V.; Biglari, P.; Fayaz, A. \& Vaziri, B. Proteomics analysis of human brain tissue infected by street rabies virus. Mol. Biol. Rep., 40(11):6443-50, 2013.

Gao, K.; Wang, C. R.; Jiang, F.; Wong, A. Y.; Su, N.; Jiang, J. H.; Chai, R. C.; Vatcher, G.; Teng, J.; Chen, J.; Jiang, Y. W. \& Yu, A. C. Traumatic scratch injury in astrocytes triggers calcium influx to activate the JNK/c-Jun/AP-1 pathway and switch on GFAP expression. Glia, 61(12):2063-77, 2013.

Hemachudha, T.; Ugolini, G.; Wacharapluesadee, S.; Sungkarat, W.; Shuangshoti, S. \& Laothamatas, J. Human rabies: neuropathogenesis, diagnosis, and management. Lancet Neurol., 12(5):498-513, 2013.

Hurtado, A. P.; Rengifo, A. C. \& Torres-Fernández, O. Immunohistochemical overexpression of MAP-2 in the cerebral cortex of rabies-infected mice. Int. J. Morphol., 33(2):465-70, 2015.

Iwasaki, Y. \& Tobita, M. Pathology. In: Jackson, A. \& Wunner, H. (Eds.). Rabies. San Diego, Academic Press, 2002. pp.283-306.

Kato, H. K.; Gillet, S. N.; Peters, A. J.; Issacson, J. S. \& Komiyama, T. Parvalbumin-expressing interneurons linearly control olfactory bulb output. Neuron, 80(5):1218-31, 2013.

Kosaka, K. \& Kosaka, T. Organization of the main olfactory bulbs of some mammals: musk shrews, moles, hedgehogs, tree shrews, bats, mice, and rats. J. Comp. Neurol., 472(1):1-12, 2004.

Kovács, T. Mechanisms of olfactory dysfunction in aging and neurodegenerative disorders. Ageing Res. Rev., 3(2):215-32, 2004.

Lamprea, N. P.; Ortega, L. M.; Santamaria, G.; Sarmiento, L. \& TorresFernandez, O. Elaboración y evaluación de un antisuero para la detección inmunohistoquímica del virus de la rabia en tejido cere- bral fijado en aldehídos. Biomedica, 30(1):146-51, 2010.

Monroy-Gómez, J. \& Torres-Fernández, O. Distribución de calbindina y parvoalbúmina y efecto del virus de la rabia sobre su expresión en la médula espinal de ratones. Biomedica, 33(4):564-73, 2013.

Nagayama, S.; Homma, R. \& Imamura, F. Neuronal organization of olfactory bulb circuits. Front. Neural Circuits, 8:98, 2014.

Ohm, T. G.; Müller, H. \& Braak, E. Calbindin-D-28k-like immunoreactive structures in the olfactory bulb and anterior olfactory nucleus of the human adult: distribution and cell typology-partial complementarity with parvalbumin. Neuroscience, 42(3):823-40, 1991.

Permyakov, E. \& Kretsinger, R. H. Calcium Binding Proteins. Hoboken, Wiley, 2011.

Prosniak, M.; Hooper, D. C.; Dietzchold, B. \& Koprowski, H. Effect of rabies virus infection on gene expression in mouse brain. Proc. Natl. Acad. Sci.U.S. A., 98(5):2758-63, 2001.

Qin, Z. P.; Ye, S. M.; Du, J. Z. \& Shen, G. Y. Postnatal developmental expression of calbindin, calretinin and parvalbumin in mouse main olfactory bulb. Acta Biochim. Biophys. Sin. (Shangai), 37(4):27682,2005 .

Sullivan, S. M. GFAP variants in health and disease: stars of the brain... and gut. J. Neurochem., 130(6):729-32, 2014.

Torres-Fernández, O.; Yepes, G. E.; Gómez, J. E. \& Pimienta, H. J. Calbindin distribution in cortical and subcortical brain structures of normal and rabies-infected mice. Int. J. Neurosci., 115(10):1375$82,2005$.

Torres-Fernández, O.; Yepes, G.; Gómez, J. \& Pimienta, H. J. Efecto de la infección por el virus de la rabia sobre la expresión de parvoalbúmina, calbindina y calretinina en la corteza cerebral de ratones. Biomedica, 24(1):63-79, 2004.

Torres, O.; Santamaría, G. \& Monroy, J. A. Dinámica neuroanatómica de infección celular en la ruta de dispersión del virus de la rabia en ratones inoculados por vía intramuscular. Biomedica, 35(Suppl. 3):113-14, 2015.

Unal-Cevik, I.; Kilinç, M.; Gürsoy-Ozdemir, Y.; Gurer, G. \& Dalkara, T. Loss of NeuN immunoreactivity after cerebral ischemia does not indicate neuronal cell loss: a cautionary note. Brain Res., 1015(12): 169-74, 2004.

van Riel, D.; Verdijk, R. \& Kuiken, T. The olfactory nerve: a shortcut for influenza and other viral diseases into the central nervous system. J. Pathol., 235(2):277-87, 2015.

Zündorf, G. \& Reiser, G. Calcium dysregulation and homeostasis of neural calcium in the molecular mechanisms of neurodegenerative diseases provide multiple targets for neuroprotection. Antioxid. Redox Signal., 14(7):1275-88, 2011.

Corresponding author:

Orlando Torres-Fernández

Grupo de Morfología Celular

Instituto Nacional de Salud (INS)

Av. Calle 26 No. 51-20

Bogotá DC

COLOMBIA

\section{Email: otorresf@ins.gov.co}

Received: $27-12-2017$

Accepted: 01-02-2018 